\title{
The Antidepressant Effects of (Arcangelisia flava (1.) Merr) Water-Soluble Extract in Balb-C Mice Reviewed from Immobility Time by Forced
}

\author{
Tiara A. ${ }^{1}$, Arief R.H. ${ }^{2 *}$ and Sudarsono ${ }^{3}$ \\ ${ }^{1}$ Faculty of Pharmacy; ${ }^{2}$ Department of Pharmacology; ${ }^{3}$ Department of Pharmaceutical Biology, UGM, Indonesia \\ Author correspondency*: \\ ar_hakim2000@yahoo.com
}

\begin{abstract}
This study was conducted to examine / determine the antidepressant effects of (Arcangelisiaflava L.) on immobility time of the white male mice strain Balb-c by the forced swim test method. The method of research using laboratory animals such as 25 micewas divided into 5 groups. As a negative control group was only given distilled water ad libitum. Amitryptiline was used as the positive control group; the experiment group was a water-soluble extract of A.flava by multiple doses. The results showed that the best antidepressant effects were 312 $\mathrm{mg} / \mathrm{kg} \mathrm{BW}$; it had a minimum of immobility time compared with the other groups.
\end{abstract}

Keywords: Acangelisiaflava, berberine, immobility time, antidepressants

\section{Introduction}

Depression is usually as a public problem. World Health Organi-zation (WHO) in 2001 stated that depression was the fourth most commonbasic problem in the world.

Symptoms of depression that appears in the form of complaints related to mood (e.g depressed, sad, despair) to make a diagnosis of depression can be easily enforced, but when psychomotor and somatic complaints that appear frequently undiagnosed depression (Amir, 2005).

Therapy for depression people are medications that can improve mood, better known as antidepressant drugs (Grollman, 1972).Antidepressant are drugs which can improve depressive symptoms. Antidepressant can be classified as desipramine type; imipramine type; amytriptylin type. This antidepressant drug has the side effects of these drugs are : due to anticholinergic properties i.e dry mouth; accommodation disorders, constipation (Mutschler, 1995), The development of local wisdom e.g. The people of West Sulawesi were using hot water soluble extract of Archangelisiaflava L. Merr for their gastrointestinal problem (diarrhoea). According to their experience in using hot water soluble of A.flavastem, could be work for the treatment of their problem. According to some references, one of the constituent of A.flava stem are a group of berberine derivative alkaloid (Siwon, 1982). This alkaloid Berberine chloride is as one of the specific active constituent that active against Shigella sp. in vitro and in vivo (Larisu, 2010). In this research of interest was to examine, that Berberine chloride constituent of the hot water soluble extract of A.flava, had an anti-depressant effect in vivo in mice. The active constituent of the A.flavais composed of alkaloid berberine, jatrorrhizin, palmatin and kolumbamin (Keawpradub et al., 2005). From the research, it was known that berberinechloride was an isoquinolinealkaloid group found in A.flava. The group of isoquinolin alkaloid had many pharmacological activities, namely as an antihypertensive, anti-inflammatory, antidepressant, anticancer, antimicrobial, hypolipidemic, hepatoprotective and antidiabetic (Singh et al., 2010).

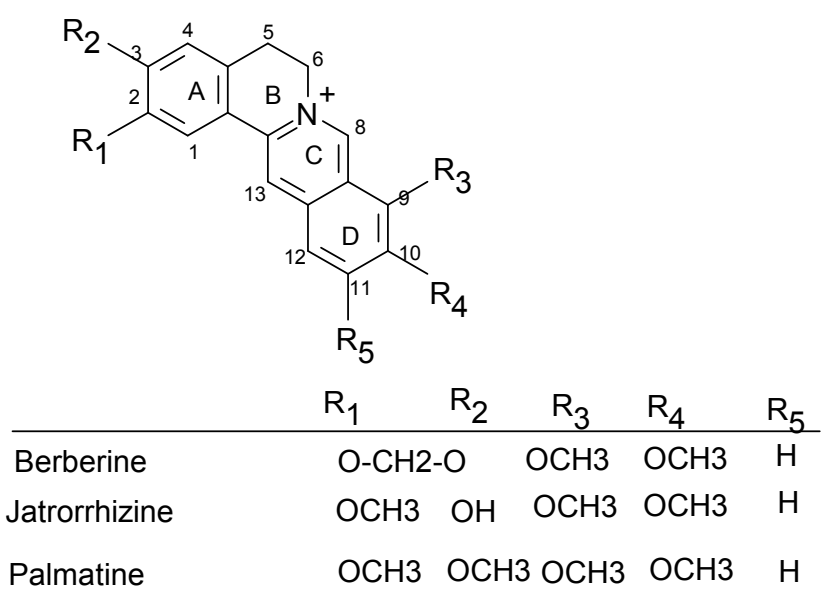

Figure 1. Berberinederivative (Siwon, 1982).

\section{Materials and Method}

\section{Plant material}

A.flava ("kayukuning") was obtained from Sorong, West Papua, Irian Jaya. This experimental plants was identified by Mr.JokosantosoM.Si and Voucher specimen was found at the department of pharmaceutical biology Faculty of Pharmacy UGM. 

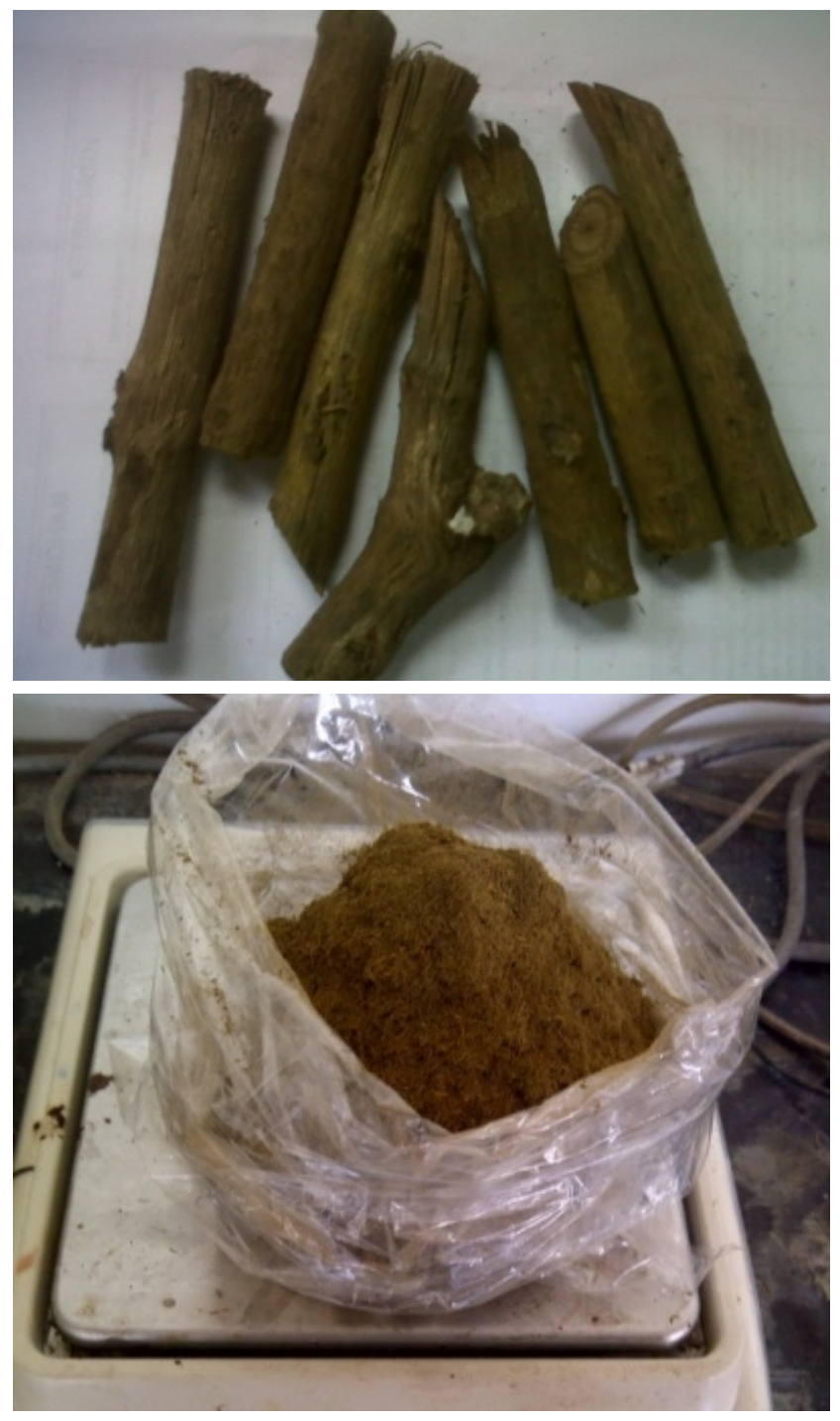

Figure 2. I. A.flava stem; II. A.flava powder.

\section{Animals}

Male white mice balb-c strain 2-3 months old, weighing 30-45 grams were used in the present study. The minimum number of animals and duration of observations required to Obtain consistent the data were employed.

Amitriptiline tablets was obtained from "Kosudgama" Drugstore UGM, was used as a positive control. The dose of the water-soluble extract containing Berberine chloride of A.flava based on empirical dose by the local people, while the administration of one dose Amitriptiline based on usage which was then converted to the test animals dose.

\section{Qualitative and quantitative Analize of Plant material}

Qualitative - quantitative analyze of Berberine chloride were done by thin layer chromato-graphy $5 \mu \mathrm{L}$.extractand reference standard berberine chloride was spotted on Silica gel $60 \mathrm{~F}_{254}$ each. Mobile phase was a mixture of $\mathrm{n}$ butanol-acetic acid and water $(3: 1: 1 \mathrm{v} / \mathrm{v} / \mathrm{v})$. The spot Visualization were $U_{254}$ and $U V_{366}$ Separated Spots was scanned between $200-700 \mathrm{~nm}$. The quantification was done by the use basic stock for $5 \mathrm{mg} / \mathrm{mL}$. Stock solution of test solution was $5 \mathrm{mg} / \mathrm{mL}$ and the several concentration of Berberine chloride in Ethanol with in 250; 200; 100; 50; dan $25 \mu \mathrm{g} / \mathrm{mL}$.

\section{Preparation of Water soluble Extract}

The extraction was done by hot water extraction method (infundation) 3,12\%. 3,12gram stem powderand $100 \mathrm{~mL}$ aquadest for 15 Minutes at $90^{\circ} \mathrm{C}$. There was $100 \mathrm{~mL}$ filtrate.

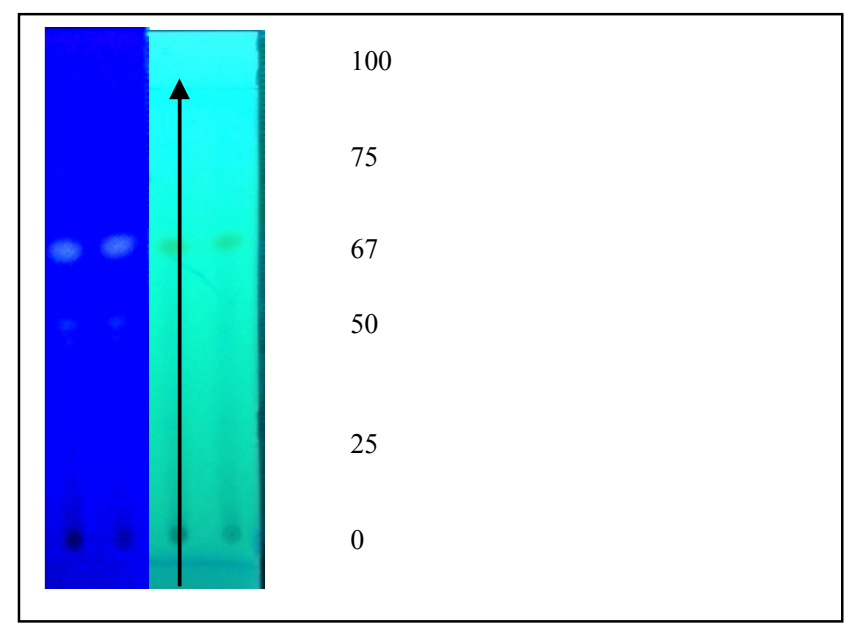

Figure 3. Preparation of Water soluble Extract.

\section{Qualitative and quantitative Analyze}

Thin layer chromatography method, was used to analyze the constituents of this extract. Quantitative analyze of the alkaloids constiturnts has done by TLC-Scanner 5 $\mu$ Lextract was spotted on the TLC plate Silica gel $60 \mathrm{~F}_{254}$ ; mobile phase was n-butanol-acetic acid-water (3:1:1 $\mathrm{v} / \mathrm{v} / \mathrm{v}$ ) for $8 \mathrm{~cm}$;Visible light, $\mathrm{UV}_{254} \mathrm{~nm}, \mathrm{UV}_{366} \mathrm{~nm}$ were used for spot detection. Scanningwas done by 200-700 $\mathrm{nm}$.

\section{Pharmacological treatments}

Forced swim test (FST) can be used as a sign of antidepressants effect.

Mice were divided into 5 groups, with the control group 2 positive control $(+)$ and negative control (-) and 3 treatment groups (P1, P2, and P3). Mice were adapted to feeding ad libitum for 1 week.After the mice were created stress by forcible allow to swim as in the forced swim test procedures on the first day up until the 14th day. Then from day 15 to day 28 , every day is oral, positive control group $(+)$ was given po at a dose of Amitriptyline were $3.25 \mathrm{mg} / \mathrm{kg}$, negative control group (-) were given a placebo in the form of distilled water, groups $\mathrm{P} 1, \mathrm{P} 2$ and $\mathrm{P} 3$ were each given a stock solution in test p.o. at a dose of 78, 156, and 312. On day 29, all groups treated with the forced swim (forced swim test) for 6 minutes and measured the immobility time. 


\section{Statistical analysis}

All results were expressed as mean \pm SD. Data were analyzed by one-way ANOVA followed by Scheffe's multiple range test. The criterion for statistical significance was $\mathrm{p} \leq 0.05$. All statistical analyses were carried out by using SPSS for Windows (SPSS Inc.).

\section{Results}

\section{Effect of water-soluble containing berberine chloride extract of A.flava}

In accordance with the forced swim test results of the testing solution, the results of immobility time in the P3 group was the shortest namely $128.6 \pm 44.8$ seconds and a negative control with an average immobility time later than the $213.6 \pm 43.6$ seconds. Based on the results of the ANOVA analysis found a significant difference only in the $\mathrm{P} 3$ group (water-soluble extract of A.flava stem with a dose of $312 \mathrm{mg} / \mathrm{kgBW}$ ) compared to the negative control group (distilled water). This indicates that the water-soluble containing berberine chloride extract of A.flavawith a dose of $312 \mathrm{mg} / \mathrm{kgBWhad}$ an effect as as an antidepressant.

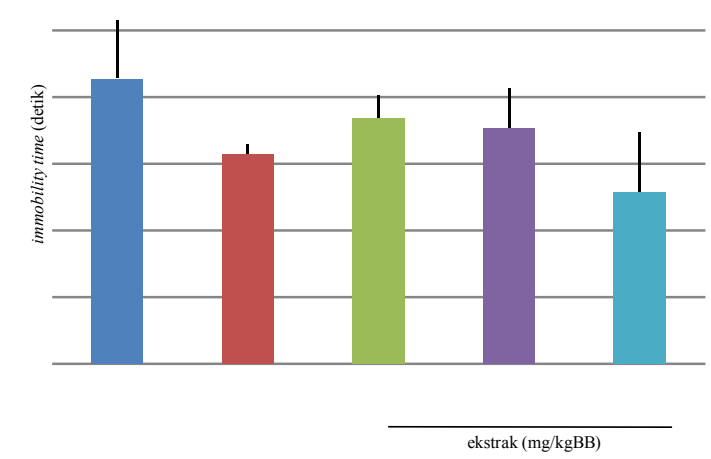

Figure 4. Influence of water-soluble containing Berberin chloride extract vs the immobility time in mice. * = Significantly different from the negative control $(\mathrm{p} \leq 0.05)$.

\section{Conclusion}

The results showed that the water-soluble extract of A.flava at a dose of $312 \mathrm{mg} / \mathrm{kgBW}$ were able to give antidepressants effect on white mice balb-c strain in terms of immobility time in the forced swim test method. As a suggestion research needs to be done the same with the number of animals per group and using comparative more pure and more detailed observation so as to give the best results.

\section{References}

Amir, N.A. 2005.Depresi: Aspek Neurobiology Diagnosis dan Tatalaksana. Penerbit FKUI. Jakarta.

Grollman, A. 1972.Pharmacology and Therapy of Depression. The American Journal of Psychiatry.113:950.

Kametani, T. 1969. The Chemistry of The Isoquinoline Alkaloids. Hirokawa Publishing Company. Tokyo. 109-111.

Larisu, M. A. 2011. Kajian Ilmiah Air Rebusan Batang Katola (Arcangelisia flava (L) Merr) Obat Tradisional Diare Berdarah Masyarakat Kabupaten Muna Sulawesi Tenggara. Tesis. Program Pascasarjana Fakultas Farmasi Universitas Gadjah Mada.

Mutschler E., Darendorf H., 1995, Drug Action, Medpharm Scientific Publisher, Stuttgart, p.126-128

Peng, W.H., Lo, K.L., Lee, Y.H.,Hung, T.H., Lin, Y.C. 2007. Berberine produces antidepressant-like effects in the forced swim test and in the tail suspension test in mice. Journal of Life Sciences. 933-938.

Porsolt, R.D., Bertin, A., Jalfre, M., 1977. Behavioral despair in mice: a primary screening test for antidepressants. Archives Internationales de Pharmacodynamieet de Therapie. 229, 327336.

Porsolt R.D, Le Pinchon M, Jalfre, M. 1977. Depression: A new animal model sensitive to antidepressant treatments. Nature. Perancis.730-732.

Singh, A., Duggal, S., Kaur, N., Singh, J. 2010.Berberin: Alkaloid with Wide Spectrum of Pharmacological Activities. Journal of Natural Product.3:64-75.

Siwon, 1982, Apharmacognostical Study of some Indonesian Plants of the family Menispermaceae, dissertation, p.73., Drukkerij J.H., Pasmans B.V,'s-Gravenhaage

World Health Organization. 2011. Depression. http://www.who.int/en/diakses Juni 2013.

Zomkowski, A.D.E., Rosa, A.O., Lin, J., Santos, A.R.S., Calixto, J.B., Rodrigues, A.L.S., 2004. Evidence for serotonin receptor subtypes involvement in agmatine antidepressant-like effect in the mouse forced swimming test. Brain Research 1023.253263. 
